\title{
LEGAL PROTECTION OF UIGHUR MUSLIM ETHNICS IN CHINA FROM PERSPECTIVE HUMAN RIGHTS
}

\author{
Endah Rantau Itasari \\ Faculty of Law Tanjungpura University \\ Jl. Prof. Dr. H. Hadari Nawawi, Bansir Laut, Pontianak, Indonesia 78124 \\ Email : endah.rantau.itasari@hukum.untan.ac.id
}

Submitted : 18/09/2020 Reviewed:11/01/2021 Accepted:17/02/2021

\begin{abstract}
Legal protection of ethnic Uighurs in Xinjiang, China in the perspective of Human Rights and to find out and study the resolution of cases of gross international human rights violations against ethnic Uighurs in Xinjiang, China. Legal protection of ethnic Uighurs based on Article 3,4,5,9,10,11, Universal Declaration of Human Rights by providing protection in the form of protection of the right to life, rights to freedom, and the right to self-security, etc. which is regulated in international legal instruments. 2) gross human rights violations committed by the Xinjiang government, China are not justified by international law because they violate the provisions stipulated in the subsequent Universal Declaration of Human Rights for incidents of human rights violations, then the dispute resolution between the two parties is carried out by negotiation or mediation first first If this method is not effective, the UN Security Council can submit the case to an international court such as the International Criminal Court set out in article 1 of the 1998 Rome Statute.
\end{abstract}

Keywords: legal protection; human rights; Uighur

DOI : 10.32801/lamlaj.v6i1.185

\section{INTRODUCTION}

Human beings as creatures of God Almighty that the task of managing and maintaining the universe with the full faith and full responsibility for the welfare of mankind, by his creator was awarded rights to ensure the existence dignity and dignity and the harmony of the environment. As part of the dignity, human rights are basic rights inherent naturally in humans, are universal and lasting, therefore they must be protected, respected, defended, and should not be ignored, reduced, or taken away by anyone. In addition to human rights, humans also have basic obligations between one human being against another and towards society as a whole in the life of society, nation and state. ${ }^{1}$

\footnotetext{
1 Undang-undang Republik Indonesia Nomor 39 Tahun 1999 tentang Hak Asasi Manusia, Indonesia (Jakarta : Legal Center Publishing 2010,) 5
} 
International law, especially after World War I, has given individuals status as independent international legal subjects in the international legal system. Individuals in international human rights law can also defend their rights directly, which initially apply to the European community in the European Convention and apply in the American Convention. The bitter and bitter experiences of mankind from world wars that have occurred twice, where the dignity of human rights is trampled on, the awareness of mankind to place respect and respect for human rights into the UN Charter as its realization emerges. then The Universal Declaration of Human Rights which was accepted by acclamation by the General Assembly of the UN General Assembly on December 10, 1948. The

state is the main, important legal subject and has the greatest authority as a subject of international law. Article 1 of the Montevideo Convention of 1933 concerning the Rights and Duties of the State as an international subject, states that the main conditions in the establishment of an independent and sovereign State are, with the existence of the territory of a State, the existence of clear State boundaries, the existence of residents as supporters in the course of a wheels of government, and the existence of a legal government so that the State has the ability to carry out or establish relations with various other international legal subjects.

Article 1 of the Montevideo Convention states that there are 3 main conditions: the existence of a state territory with clear territorial boundaries, the existence of a population to support the running of a government, the existence of a legitimate government, and it has been recognized since the 19th century in Europe., and what is known as an additional requirement is the fourth requirement, which is, the ability to carry out or establish relations with various international legal subjects. The criteria for granting recognition to a new State are based on or guided by several things, which is: the belief in the existence of stability in that country, general support from the people or people of the country concerned, willingness to carry out international obligations.

The state as a subject of international law is a party that certainly has an obligation to protect, guarantee and fulfill human rights (HAM). State obligations related to human rights internationally are regulated in various international human rights law instruments, namely: Universal Declaration of Human Rights, hereinafter abbreviated as UDHR, International Covenant on Civil and Political Rights hereinafter abbreviated as ICCPR, The International Covenant On Economic, Social and Cultural Rights, hereinafter abbreviated as ICESCR. Article 2 of the Universal Declaration of Human Rights (UDHR) of 1948 states that the law or international position of the country or region where a person comes from, whether from an independent state, is in the form of guardianship, colony or those that are under the boundaries of sovereignty. other. $^{2}$

It is affirmed by the statement in UDHR 1948 that everyone has the right to life, the right to freedom and safety as an individual. Furthermore, there will be no difference on the basis of political position. Human rights in practice or implementation are regulated in

\footnotetext{
2 Dewa Gede Sudika Mangku and I. Wayan Lasmawan, "Perlindungan Hukum Terhadap Kaum Etnis Uighur Dalam Perspektif Hak Asasi Manusia Internasional," Jurnal Komunitas Yustisia 3, no. 1 (2020): 231-240.
} 
international law. Several international legal experts provide various definitions of human rights, including the following: Life becomes full of dignity when the majority of people understand and understand human rights which are basic or fundamental rights. ${ }^{3}$

In Article 1 of the Law of the Republic of Indonesia Number 39 of 1999 concerning Human Rights, it explains that human rights are a set of rights inherent in the nature and existence of every human being as a creature of God and is a gift given by God which of course must be respected, upheld, and protected by the law of the government of the State, as well as everyone for the honor of protection of human dignity. Article 3 of Law No. 39/1999 concerning Human Rights contains discrimination. Discrimination is a limitation, harassment or exclusion carried out directly or indirectly on the basis of human differentiation on the basis of religion, ethnicity, race, ethnicity, group, class, social status, economic status, gender, language and political beliefs, which can be resulting in the reduction, deviation, or elimination of the recognition, implementation or use of Human Rights and basic freedoms in life both individually and collectively, especially in the political, economic, legal, social and other aspects of life. Thus, factors such as race, gender, religion, or language cannot confirm the manifestation or existence of Human Rights in humans themselves. ${ }^{4}$ Uighur is one of the official minority

\footnotetext{
3 Muhammad Fajrin Saragih, Sulaiman Hamid, and Makdin Munthe, "Tinjauan Yuridis Pelanggaran Ham Terhadap Muslim Uighur Di China Ditinjau Dari Hukum Humaniter," Journal of USU International Law 4, no.2 (2016): 164, https://jurnal.usu.ac.id/ index.php/ji1/article/view/13344.

${ }^{4}$ Andrey Sujatmoko, Hukum HAM Dan Hukum Humaniter (Jakarta: PT Raja Grafindo Persada, 2015), 2
}

tribes in the Republic

People's of China (PRC), where the Uighurs themselves are descended from ancient tribes that have spread across Central Asia. The Uighur ethnic community has experienced various forms of human rights violations to date, the forms of human rights violations accepted by the ethnic Uighur community are torture and coercion to no longer embrace Islam and they are exiled and even shot to death, which in the end is for the actions that have been committed. by the Xinjiang government caused many victims both children and adults. Based on this description, the researcher found a problem, thai is: the problem boundaries described above, the author raised the problem, it is the Legal Protection of Ethnic Uighur Muslims in China in a Human Rights Perspective.

\section{METHOD}

Normative legal research is a type of legal research used in this study. Normative legal research rests on a method that focuses on library law research using library materials, as well as statutory regulations. This type of legal research uses the type of normative research which systematically studies and analyzes legal protection against human rights violations that befall the Uighur Muslim ethnicity in China.

In this legal research, an approach based on statutory regulations (statute approach) and aconceptual approach is used. The statute approach is an approach using laws and regulations relating to legal issues that will be discussed in depth. This approach is based on written legal provisions, namely statutory regulations that are specifically related to the Legal Protection of Ethnic Uighur Muslims in China in a Human Rights Perspective. 
Legal research distinguishes two types of research into two types, namely legal decisions related to the variables studied or called das sollen and facts related to research variables or called das sein. Data in the form of legal decisions and legal facts comes from primary data and secondary data. Data sourced from primary data is data obtained directly from those who live the data, while data that comes from secondary data is the power that comes from parties who do not directly share the data..$^{5}$ This study emphasizes secondary data sources as the main data obtained through library research.

Secondary data is research data obtained from literature, consisting of: a) Primary legal material, namely the Universal Declaration of Human Rights, hereinafter abbreviated as UDHR, International Covenant On Civil And Political Rights hereinafter abbreviated as ICCPR, The International Covenant On Economic, Social And Cultural Rights, hereinafter abbreviated as ICESCR. B) Secondary legal materials are legal materials that have the property of providing explanations for primary legal materials. This legal material includes legal literature in the form of legal science doctrine in state administrative law, and can provide an explanation of the problems in research. C) Tertiary legal materials, legal materials that have supportive properties, because they can provide guidance and explanation for primary and secondary legal materials, consisting of: Encyclopedia, Big Indonesian Dictionary and Black's Law Dictionary.

Data analysis is an activity of analyzing data that researchers have collected, either obtained through library research or through field research. The analysis is carried out by classifying, systematizing, which is then evaluated to support the resolution of the problem being studied, in the hope that the right conclusions will be obtained.

The first step is through the classification and data systematization stage. Classification and systematization of data is carried out by classifying library materials based on the specific characteristics of legal materials in the form of statutory provisions, concepts, principles and / or theories (das sollen), as well as circumstances or facts (das sein) relating to existing problems.

The second step is to interpret the research data. Interpretation is carried out by the author to determine the appropriate data for reference, because not all of the collected data is relevant to the research, for example its accuracy is doubtful because it does not come from the right source.

The third step is to evaluate, which is a step to explain the relationship between one variable and another in accordance with the problem formulation. Thus, through the stages that have been carried out, the problems raised in this study are expected to find answers.

The method used to analyze the data is a qualitative method, which is an in-depth and comprehensive analysis. The consideration of the use of qualitative methods is based on the consideration that there are various kinds of data analyzed, the nature of each data is different, and it is not easy to quantify. In addition, the nature of the data is comprehensive, and is aholistic whole. These characteristics can be captured by a variety of data, and require in-depth information.

\footnotetext{
${ }^{5}$ F. Sugeng Istanto, Penelitian Hukum (Yogyakarta: CV Ganda, 2007), 56-57
} 


\section{ANALYSIS AND DISCUSSION The Human Rights Rights The Fundamen- tal and Universal}

The Concept of Human Rights (HAM) includes three primary elements of human existence both as individual beings and social beings, which are called the integrity of the human (humanintegrity), freedom(freedom) and parity (equality). ${ }^{6}$ These three elements are conceptualized into definitions and understandings of what human rights are.

The understanding of this understanding becomes clear when the recognition of these rights is given and is seen as a humanization process by other parties in a vertical (individual to state) and horizontal (between individuals) context, both de facto and de jure. Thus, human rights values are fundamental and universal with the recognition, protection and promotion of human integrity, freedom and equality in the main international human rights instruments, at the international, regional and national levels. Although the values are universal, human rights can be divided into several academic normative groupings, namely, first, or personal rights "personal rights". Second, economic human rights or the right to own something ("property rights"). Third, the right to get equal and equal treatment in law and government or the "right of legal equality". Fourth,or "political rightspolitical rights". Fifth,or "social and cultural rightssocial and cultural rights", such as obtaining and choosing education, develop a preferred culture. Sixth, the right to litigate and protect it or "procedural rights". The understanding and understanding of human rights in terms of

\footnotetext{
6 Asbjorn Eide, Catarina Krause and Allan Rosas, Economic, Social and Cultural Rights, A Textbook, (Norwell Massachusetts, Boston : Martinus Nijhoff, Dordrecht, 1995), 21.
}

this substance becomes complex and complex based on developments, existing realities and the complexity of other determinants.

Human rights concepts and values change over time through both evolutionary and revolutionary processes from normative forces into processes of social and political change in the entire order of human life. ${ }^{7}$ Thus, the understanding of the meaning of human rights in terms of substance must be returned to the basic concept of why human rights exist. Human rights exist and arise because these human rights are very basic in nature in the sense that their implementation is absolutely necessary so that humans can develop according to their talents, aspirations, and dignity as human beings regardless of differences that cause discrimination based on nation, race, religion and gender. The principles of understanding human rights must be used as the main basis so that the understanding of human rights from a substantive perspective can be applied. These principles are the application of the concept of indivisibility and the interdependence of human rights values themselves. ${ }^{8}$

According to his ontology, human rights are rights owned by humans that are obtained and carried along with their birth or presence in society because they have a privilege that opens the possibility for them to be treated

\footnotetext{
7 Bonanza Perwira Taihitu, "Penaatan Indonesia Pada Standar-Standar HAM Internasional Dalam Kurun Waktu 1991-2002" (Fakultas Ilmu Sosial dan Politik Departemen Ilmu Hubungan Internasional, Pascasarjana Universitas Indonesia, 2003), 38.

8 “UN Children's Fund (UNICEF), “A Human Rights Approach to UNICEF Programming for Children and Women : What It Is and Some Changes It Will Bring," Refworld, last modified 1998, https://www. refworld.org/docid/3f82adbb1.html.
} 
according to these privileges. ${ }^{9}$ In a simpler sense, human rights are the rights of a person, if that right is taken away from him, it will result in that person becoming no longer human. ${ }^{10}$

Human rights, as understood in human rights documents that emerged in the twentieth century such as the Universal Declaration of Human Rights (DUHAM), have a number of prominent characteristics, namely: ${ }^{11}$ First, so that we do not lose clear ideas, rights human rights are rights. The meaning of this term is unclear, but at least it shows that it is a definite and high priority norm for which enforcement is mandatory. Second, these rights are considered to be universal, which are owned by humans solely because they are human. This view implies that characteristics such as race, gender, religion, social position, and nationality are irrelevant in questioning whether a person has or does not have human rights. It also implies that these rights can be applied worldwide. One of the special features of human rights currently in effect is that they are international rights. Adherence to such rights has been viewed as an object of legitimate international concern and action.

Third, human rights are assumed to exist independently, and do not depend on their recognition and application in the customary or legal systems of certain countries. This right may be is not yet an right effective until it is executed according to the law, but

\footnotetext{
9 Theo Huijbers, Filsafat Hukum (Yogyakarta : Kanisius, 1990), 96.

${ }^{10}$ United Nations, Human Rights, Questions and Answers, (United Nations Department of Public Information, New York, 1998), 4

${ }^{11}$ James W Nickel, Making Sense of Human Rights: Philosophical Reflection on the Universal Declaration of Human Rights (The Regents of the University of California : University of California Press, 1987), 10
}

right to theexist as a standard argument and criticism is not dependent on the application of the law. Fourth, human rights are seen as important norms. Although not entirely absolute and without exception, human rights have a strong enough position as a normative consideration to be enforced in conflict with conflicting national norms, and to justify international action taken for the sake of human rights. The rights set out in the Declaration are not arranged according to priority; their relative weights are not specified. It is not stated that some of them are absolute.

The human rights described by the Declaration are what philosophers call prima facie rights. Fifth, these rights imply obligations for both individuals and governments. The existence of this obligation, as well as the rights related to it, is deemed independent of its acceptance, recognition or application. Governments and persons everywhere are obliged not to violate a person's rights, although the government of that person may at the same time have the primary responsibility to take positive steps to protect and enforce that person's rights. Sixth, these rights establish minimum standards for proper social and state practice. Not all problems that are born of cruelty or selfishness and ignorance are human rights problems. For example, a government that fails to provide national parks for its people can be denounced as incompetent or not paying enough attention to opportunities for recreation, but that will never become a human rights issue.

The state and each individual have their own role in the implementation of human rights. The role of individuals is related to the principle of balance as stated above, namely that human rights do not only contain authority or freedom but also individual responsi- 
bilities or obligations, and each individual as a human rights subject has the obligation or responsibility to respect the human rights of others, as well as other people being demanded. to respect his human rights. Violation of one's human rights by another individual is an act that can be held accountable legally.

The role of the state is very central and important in the implementation of human rights. Referring to various human rights instruments, it is a state that has the obligation to ensure the fulfillment of human rights. The state has an obligation to ensure that human rights are respected, protected, promoted and fulfilled. Respect (to respect), shield (to protect), advancing (to promote) and meet (to fulfill)shows the level of action or actions to be taken by the state in relation to the implementation of human rights. Respect is the government's most "minimal" action (in the form of negative action, in the sense of not committing violations), and fulfilling is the state's obligation to take the most "full" effort for the realization of human rights. ${ }^{12}$

The nature of state obligations mandated in international human rights instruments with regard to the implementation of human rights differs between civil and political rights, and economic, social and cultural rights. For civil and political rights, the ICCPR obliges the state to "immediately" take the necessary steps in the field of legislation or other steps in order to respect and ensure the implementation of these civil and political rights. As for economic, social and cultural rights, the ICESCR obliges the state to take steps, taking

\footnotetext{
${ }^{12} \mathrm{Ni}$ Putu Rai Yuliartini and Dewa Gede Sudika Mangku, "Tindakan Genosida terhadap Etnis Rohingya dalam Perspektif Hukum Pidana Internasional," Majalah Ilmiah Cakrawala Hukum 21, no. 1 (2019): 41-49, http://e-journal.unwiku.ac.id/hukum/index.php/CH/ article/view/51
}

into account the maximum resources it has, in order realize to progressivelythese economic, social and cultural rights.

This is understandable because realizing civil and political rights does not require large economic resources as in economic, social and cultural rights. However, this does not mean that the state is only obliged to take measures to realize these economic, social and cultural rights when the state has reached a certain level of economic growth. Regardless of the capacity of the economic resources or other resources, a country should move as soon as possible towards the realization of these rights. Moreover, there are several rights guaranteed in the ICESCR which relatively do not require large economic resources. The state, for example, can immediately reform laws that are discriminatory in nature, or that prevent people from enjoying their rights, or laws and regulations that "facilitate" violations of rights by the state. Measures like these don't have to wait for the country to truly prosper. ${ }^{13}$

A country ratifies an instrument international human rights, it can directly incorporate the provisions of that instrument into its domestic legislation and or through other measures. Human rights implementation can be carried out as well as possible if good legislation, an independent judiciary and established democratic institutions are available. In addition, education and dissemination of human rights values also isan important effort in the framework of the implementation

\footnotetext{
${ }^{13}$ Dewa Gede Sudika Mangku, "Kasus Pelanggaran Ham Etnis Rohingya: Dalam Perspektif ASEAN," Media Komunikasi FPIPS 12, no.2 (2013): 60-69, https:// ejournal.undiksha.ac.id/index.php/MKFIS/article/ view/1708.
} 
of human rights. ${ }^{14}$

\section{History of Ethnic Uighurs The}

Uighurs are a minority ethnic group in the Xinjiang region, located on the western and northwestern tip of China. This tribe has its own province with an autonomous status called Xinjiang-Uighur. The majority of the Uighurs are Muslim. "Uighur" itself means union or fellowship. Uighur Muslims speak the local language and are Turkmen. They wrote in Arabic. According to Anshari Thay$\mathrm{ib}$, in the book Islam in China published by Amarpress, the beginning of Islam's entry into Xinjiang was when the Uighur community acted as intermediaries for trade between China and the West. Historically, the Xinjiang region used to be known as "East Turkistan".

The area of East Turkistan alone reaches 1.6 million square kilometers or one-fifth of the area of China. Thanks to long interactions with Arab, Persian and Turkish traders, the Uighur community began to recognize and embrace Islam. The number of Uighur Muslims in 2011 was around 8 million. Meanwhile, the number of Muslims in China in 2011 was around 20 million out of China's total population of 1.3 billion. ${ }^{15}$

Since the Communist government's takeover of the Turkistan region in 1949, the number of communist Han Chinese in the region has increased from $6.7 \%$ to $40.6 \%$, according to official figures. They are the ones who later

\footnotetext{
${ }^{14}$ Ketut Arianta, Dewa Gede Sudika Mangku, and Ni Putu Rai Yuliartini, "Perlindungan Hukum Bagi Kaum Etnis Rohingya Dalam Perspektif Hak Asasi Manusia Internasional," Jurnal Komunitas Yustisia 3, no. 2 (2020): 93-111, https://ejournal.undiksha.ac.id/ index.php/jatayu/article/view/28849.

${ }^{15}$ Saragih, Hamid, and Munthe, "Tinjauan Yuridis Pelanggaran Ham Terhadap Muslim Uighur Di China Ditinjau Dari Hukum Humaniter."
}

appear to be in control of all major political functions and activities in the Xinjiang region. With the support of the Chinese government, they also enforce conditions that isolate and restrict the performance of religious rituals, and prohibit Uighur Muslims from using their language in schools. ${ }^{16}$

Starting from these discriminatory policies resulted in conflict between Uighur Muslims and the Chinese government as well as ethnic conflict between Uighurs and Han tribes. The Chinese government is marginalized due to the fact that the Xinjiang region has abundant natural resources. Before being colonized by the Chinese communist government, in the 1940s, the East Turkistan Republic had emerged in parts of Xinjiang which were considered part of their human right to independence. ${ }^{17}$

However, the establishment of the East Turkistan Republic was not recognized by the Chinese communist government. China considers Xinjiang a part of its territory. Even Mao Zedong immediately sent troops to Xinjiang in 1949. At its peak, on October 1, 1955, Xinjiang was officially made a province with the status of an autonomous region despite the fact that the majority of its population at that time was Uighur.

\section{Legal Protection Against Human Rights Violations That Befall Ethnic Uighur Mus- lims in China}

Internationally, human rights are included in an international legal system established by the international community consisting of states. The state has an important role in shaping such a legal system, namely through international customs, international agreements or other forms such as declarations or techni-

\footnotetext{
${ }^{16}$ Ibid.

${ }^{17}$ Ibid.
} 
cal guidelines. Then the country declares its agreement and is bound by international law. Human rights provide protection which can be in the form of an individual, group or property. The state or state officials as part of the state have an obligation in the international scope to protect citizens and their assets. International human rights standards are established and developed in various negotiations in international forums. ${ }^{18}$

The process of establishing this standard is carried out by representatives of each country in an international forum which has gone through a long process with a long period of time. This formation process not only discusses the substance and form of a draft declaration and agreement to be agreed upon, but can be discussed in detail in articles, word for word proposals from the contents of the agreement can then be agreed upon into an international treaty by countries. The UN Charter, committed to fulfilling, protecting human rights and respecting the basic human freedoms universally is emphasized repeatedly, including in article 1 number 3 which states to promote international cooperation in solving international problems that occur especially in the economic, social, cultural fields. , and humanity, and defeating and promoting respect for human rights and fundamental freedoms for all persons regardless of race, sex, language or religion. This commitment was then followed up by the UN through the establishment of legal instruments regulating

18 I Dewa Ayu Nyoman Alit Mahardini, Dewa Gede Sudika Mangku, and I. Wayan Lasmawan, "Perlindungan Hukum Terhadap Petugas Medis Dalam Konflik Bersenjata Dalam Perspektif Hukum Humaniter Internasional (Studi Kasus: Penembakan Petugas Medis Razan Al Najjar Di Jalur Gaza)," Jurnal Komunitas Yustisia, 3 no. 1 (2020): 221-230. human rights. ${ }^{19}$

The chronology of cases of human rights violations against ethnic Uighurs, in general, initially starting from the Chinese government, which is a Communist country and ethnic Uighurs, which are the fourth largest ethnic group in East Turkistan and embracing Islam, certainly cause concern especially for the Chinese government. Because, the Chinese government thinks that the things that Uighurs adhere to and do can result in a cultural shift in China, especially in the Xinjiang area. So, to avoid things that China doesn't want, the Chinese government creates and builds special camps for ethnic Uighurs such as foundations or schools. ${ }^{20}$

With the aim that the Uighur ethnic community does not deviate and with the aim of providing a nationalist understanding and thinking so that there is no cultural shift in the Xinjiang region. However, in the applications carried out by the Chinese government, there are actions that are deemed unnatural and incompatible with humanity. The actions taken by the Chinese government by building places on the pretext of schools or foundations to teach the culture and nationalist spirit to the Uighur ethnic community is an act that violates human rights and the actions taken are also a form of discrimination against one particular ethnicity, namely the Uighur ethnicity.

About 1 million ethnic Uighurs reside in

19 Endah Rantau Itasari, "Hak Untuk Pendidikan yang Diterima oleh Masyarakat Indonesia di Perbatasan Darat dalam Persepktif Hak Asasi Manusia," Majalah Ilmiah Cakrawala Hukum 21, no. 1 (2019): 31-40, http://e-journal.unwiku.ac.id/hukum/index.php/CH/ article/view/50

${ }^{20}$ Endah Rantau Itasari, "Fulfillment Of Education Rights In The Border Areas Of Indonesia And Malaysia," Ganesha Law Review 1, no. 1 (2019):113, https://ejournal2.undiksha.ac.id/index.php/GLR/ article/view/14/ 
camps set up by the Chinese government. This is known, when one of the international media belonging to the United States, The New York Times, officially reported that what was happening inside the camps did not look like a place to study but rather a place for detention of ethnic Uighurs or brainwashing. The New York Times reported that there is a document from China's leader, Xi Jinping, ordering officials to take merciless action against separatism aimed at the ethnic Uighur minority group. ${ }^{21}$

The document, which is approximately 403 pages thick, states that $\mathrm{Xi}$ Jinping provided directions to supervise, control, regulate and suppress the ethnic Uighur population. The Chinese government, commits human rights violations aimed at ethnic Uighurs in various actions and efforts by depriving Uyghurs of human rights, such as: Prohibiting ethnic Uighurs from practicing religion or practicing worship properly, Committing acts of violence, acts of discrimination, acts of slavery, acts of persecution and torture that injures physically and mentally, as well as acts of threat, even to the occurrence of acts of murder against the Uighur ethnic community that have been committed by the Chinese government. So that these violations committed by China have usurped various basic rights that the Uighurs should have, namely: the right to life, the right to freedom of opinion, the right to express the aims and objectives, the right to freely practice a religion that is d nut, the right to get a decent job and education, the right to associate with family, and

\footnotetext{
${ }^{21}$ Kamran Dikarma, "Dokumen Tunjukkan Tindakan Keras China Ke Muslim Uighur," REPUBLICA. CO.ID, last modified 2019, https://republika.co.id/ berita/q13ymw328/dokumen-tunjukkan-tindakankeras-china-ke-muslim-uighur .
}

other rights. ${ }^{22}$

The gross human rights violations committed by the government of Xinjiang, China against the ethnic Uighurs constitute a crime against a group of human beings by discriminating against, forcibly detaining and expelling them and by systematically structured actions. The Uighur ethnicity in this caasus is not given freedom in carrying out their worship and religion. This happens during the months of Ramadan, when Uighurs should fast and pray. ${ }^{23}$ However, it is not permitted and to carry out these activities. If anyone tries or violates the things that have been determined, they will be arrested or punished and put in a recovery camp, which is actually a brainwashing camp so that the Uighur ethnic community does not live a religious life as it should be in accordance with their rights and freedoms. .

Ways or steps, to reduce and combat racial discrimination that has been made by the United Nations against an ethnicity by adopting a number of resolutions as well as conventions and declarations. In the first world conference to eradicate racism and racial discrimination that exists and is occurring, every country is urged to immediately eliminate discrimination because of any background, whether in the form of ethnic or national differences among their citizens. The state is also required to protect and promote human

\footnotetext{
${ }^{22}$ Endah Rantau Itasari, "Implementasi Pemenuhan Hak Pendidikan Warga Negara Indonesia Di Perbatasan Darat Antara Indonesia Dan Malaysia," Jurnal Ilmiah Ilmu Sosial 4 no. 2 (2018): 181-186, https://ejournal. undiksha.ac.id/index.php/JIIS/article/view/16534.

${ }^{23}$ Ani Nursalikah, "Cina Tindak Keras Muslim yang Berpuasa Ramadhan," REPUBLICA.CO.ID, last modified 2019, https://republika.co.id/berita/ pr671 p366/cina-tindak-keras-muslim-yangberpuasa-ramadhan.
} 
rights as well as for minority ethnic groups and national groups. The Conference which took place among these countries was recommended to immediately adopt special measures, especially in the fields of economic, social, educational, cultural and civil and political rights.

The Chinese government has committed human rights violations in Xinjiang, including violations of religious freedom, where as reported by international newspapers, that the Chinese government authorities prohibit ethnic Uighur Muslims in Xinjiang from carrying out activities and obligations to worship according to their religion, Uighur Muslims are also prohibited from performing rituals. such as prayer and fasting during the month of Ramadan, mosques are heavily guarded by the CCP government security forces, Uighur Muslims are also prohibited from entering mosques and praying, officials even distribute food and drinks to Uighur Muslim homes during the holy month Ramadan and forcing Uighur Muslims not to fast, however, the CCP Government argues this is done to maintain security and stability for the country. ${ }^{24}$

Apart from freedom of religion, the Chinese government also committed other human rights violations, namely freedom of assembly and opinion, barriers to education, discrimination, and the death penalty for political prisoners. Apart from the mosques are heavily guarded, even the existence of Islamic and Imam schools is strictly controlled by the CCP government, and imams are required to "stand on the side of the government" in or-

\footnotetext{
24 "Chinese Torture in East Turkestan," Harun Yahya, accessed January 1, 2021, https://m.harunyahya. com/tr/books/582/Communist-China's-Policy-ofOppression-in-East-Turkestan/chapter/66/ChineseTorture-in-East-Turkestan.
}

der to carry out propaganda for Uighur Muslims. ${ }^{25}$

From 1995 to 1999, the Chinese government collapsed 70 places of worship and revoked the licenses of 44 priests who did not support the government. The government also officially enforces a ban on individual worship in state-owned places, Economic discrimination is also carried out by the Chinese Government against ethnic Uighur Muslims, Most Uighur Muslims have difficulty finding work in their own places, they are often subjected to violent actions at home. places of public service, where most Uighur Muslims do not find strategic jobs when compared to the Han people. ${ }^{26}$

According to Amnesty International, Xinjiang is the only province in China that allows the death penalty for political prisoners. The exact number of victims of political prisoners sentenced to death is hidden by the Chinese state, but according to Dogu Turkistan, the death toll from the death penalty or torture by the Chinese government reached 2,500 from 1999 to March 2000 alone. The discrimination experienced by Uighur Muslims is a policy of the Chinese government which wants the realization of the One China Policy or the one China policy.

The Chinese government's integrative patterns by conducting civic education have proved unsuccessful in integrating Uighur Muslims with other majority Chinese populations. Indeed, it has ethnic Uighurs fought for migration policy the Chinese Government to make the shift massive ethnic Han who is

\footnotetext{
25 "Chinese Torture in East Turkestan," Harun Yahya, accessed January 12, 2015, https://m.harunyahya. $\mathrm{com} / \mathrm{tr} /$ books/582/Communist-China's-Policy-ofOppression-in-East-Turkestan/chapter/66/ChineseTorture-in-East-Turkestan.

${ }^{26}$ Ibid.
} 
an ethnic majority to the area of Xinjiang and Urumqi, massive migration is none other than the form of government policy china to conduct ethnic cleansing (genocide ) to gradually remove Uighur Muslims from the Xinjiang and Urumqi regions, in addition to China's family planning policies benefiting the Han people, who have a population growth rate of 31.6 higher than other tribes with a maximum of $15.9 \%$, the family planning policy in China is also claimed to be part of the Chinese government's policy to carry out ethnic cleansing. ${ }^{27}$

The Geneva Convention (Red Cross Convention) of 1949 regarding the protection of victims of war and non-international armed disputes can be used as a reference in protecting the Uighur Muslim people. In accordance with the chronology of the incidents of crimes against humanity that occurred against Muslims in the Uighurs that have been described previously which became the spotlight of the international community which consumed many civilians, it is better if the UN Security Council sees this as a violation of human rights and also violates international law because there is no protection against it. civilians in the Uighurs. In this consideration encouraging the establishment of the Rome Statute by countries in the highest UN forum. ${ }^{28}$

The Rome Statute has provisions which can be categorized as jus cogens and is erga omnes in nature. Because of this, the Statute's regulations are universally binding and apply to all citizens of the world, either directly

\footnotetext{
27 "Human Rights Watch Background Briefings -> Asia -> China," Human Rights Watch, last modified 1999, accessed January 1, 2021, https://www.hrw.org/ legacy/backgrounder/asia/china/.

${ }^{28}$ Saragih, Hamid, and Munthe, "Tinjauan Yuridis Pelanggaran Ham Terhadap Muslim Uighur Di China Ditinjau Dari Hukum Humaniter.”.
}

or indirectly. This means that the Statute is binding not only for the participating countries that have ratified it, but also for countries that have not or are included as participants, namely China. ${ }^{29}$ Cases of crimes against humanity against Muslims in the Uighurs, such as murder, torture, burning schools, destroying places of worship and not having the freedom to practice belief in worship by the authorities, in this case the state of China, still has the possibility for the International Criminal Court to exercise its competence and jurisdiction over This case, due to the facts that occurred in the case of crimes against humanity against Muslims in Uighur, the material requirements set out in the Rome Statute, especially those in Article 7, have to do with crimes against humanity. ${ }^{30}$

This is aimed at ensuring that all people around the world will enjoy such a thing as legal equality and harmony. So, it can be a guarantee that discrimination that occurs between the majority group and the minority group has been eliminated or minimized. International instruments that have regulated legal protection for ethnic Uighurs, whose ethnicity has experienced discrimination and treatment that is not in accordance with international human rights by the Xinjiang government in China. The governing conventions are: The Convention on the Prevention and Punishment of

\footnotetext{
${ }^{29}$ Raihan Taqy, Joko Setiyono, and Soekotjo Hardiwinoto, "Tanggung Jawab Negara Suriah Terhadap Konflik Antara Pemerintahan Bashar AlAssad Dengan Pemberontak Di Suriah Dari Perspektif Hukum Humaniter Internasional," Diponegoro Law Journal 5, no. 2 (2016): 1-13, https://ejournal3.undip. ac.id/index.php/dlr/article/view/11146.

${ }^{30}$ Bhatara Ibnu Reza, "Menguak Penghilangan Paksa: Suatu Tinjauan Dari Segi Politik Dan Hukum Internasional," Indonesian Journal of International Law 1, no. 4 (2004): 769, ijil.ui.ac.id/index.php/ home/article/view/567.
} 
the Crime of Genocide was adopted by UN General Assembly Resolution 260 A (III) on 9 December 1948. This convention is in effect since 12 January 1951. Then the Convention On The Prevention And Punishment Of The Crime Of Genocide is the first human rights treaty ratified by the general assembly of the United Nations. This Convention focuses attention on protecting national racial, ethnic and religious minorities from threats to their existence, especially in terms of discrimination. Article 2 of the Convention on the Prevention and Punishment of the Crime of Genocide protects the existence of an ethnic group from all acts that may cause the partial or complete extinction of a certain ethnic group either by preventing the birth of a baby in that ethnic group or the loss of the life of a person belonging to the group. the. The perpetrator of the crime of genocide, or the one who planned the crime of genocide, whether it is a constitutionally responsible leader, a public official, or an individual can be tried in a court in the State where the crime of genocide was committed or resolved through an international court that has jurisdiction. The cases that occurred in Xinjiang related to human rights violations against ethnic Uighurs can be brought to trial because they have led to the crime of genocide. Therefore, the Chinese government has the right to be tried in relation to the problems that occur in the country.

\section{CONCLUSION}

legal protection given to ethnic Uighurs, in this case the case that occurred in Kosovo, Yugoslavia, can be used as a reference for making rules or policies on equal rights between ethnic Uighurs and Chinese, establishing temporary courts as a solution, the existence of responsibility Protect from groups, communities or international organizations if the state is negligent in protecting its citizens from the crime of genocide. Forms of legal protection for ethnic Uighurs The UN Human Rights Council can also investigate problems that occur and form an international committee, and can take the form of implementing policies that have been regulated in international legal rules. Legal protection for ethnic Uighurs is also based on articles 3, 5, 9, 10 and 11, the Universal Declaration of Human Rights (DUHAM) is to provide protection to ethnic Uighurs in the form of the right to life, the right to freedom and personal security, the prohibition of torture. human dignity. Legal protection in the International Covenant on Civil and Political Rights of 1966 is the protection of the right to life, the right not to be tortured, treated or punished cruelly, the right to freedom, and the right to personal security. International Covenant on Economic, Social and Cultural Rights, Convention on Genocide, International Convention against Torture, International Convention on the Elimination of All Forms of Racial Discrimination 1965, Convention on the Elimination of All Forms of Discrimination Against Women and Convention on the Rights of the Child. International dispute resolution, related to gross human rights violations against ethnic Uighurs under article 33 of the UN Charter, the disputing parties (ethnic Uighurs and the Government of Xinjiang, China) can resolve problems that occur through peaceful settlement methods, through political channels using negotiations carried out between the Uighurs and the Xinjiang Government as well as through mediation using a moderator as a third party to help problems that occur between the two parties. If this method is not yet relevant or successful, the UN Council can submit 
cases that occur to international courts such as theInternational Criminal Court (ICC) as regulated in article 1 of the 1998 Rome Statute.

\section{Suggestions}

Based on these conclusions, there are suggestions that the authors can submit as follows: 1) The government of Xinjiang, China should immediately stop violence against ethnic Uighurs because their actions violate the principles of world peace and security. 2) The government of Xinjiang, China has committed human rights violations in the form of crimes, discrimination and oppression or others, which constitute crimes against humanity against ethnic Uighurs. So, in this case the UN Security Council has a role to protect ethnic Uighur Muslims. If the settlement carried out through political channels in the form of negotiation or mediation does not go well and as it should. So, problems can be resolved through theInternational Criminal Court(ICC).

\section{BIBLIOGRAPHY}

\section{Books}

Eide, Asbjorn, Catarina Krause and Allan Rosas. Economic, Social and Cultural Rights, A Textbook. Norwell Massachusetts, Boston : Martinus Nijhoff, Dordrecht, 1995.

Huijbers, Theo. Filsafat Hukum. Yogyakarta : Kanisius, 1990.

Istanto, F. Sugeng. Penelitian Hukum. Yogyakarta: CV Ganda, 2007.

Nickel, James W. Making Sense of Human Rights: Philosophical Reflection on the Universal Declaration of Human Rights. The Regents of the University of California : University of California Press, 1987.

Sujatmoko, Andrey. Hukum HAM Dan Hukum Humaniter. Jakarta: PT Raja Grafindo
Persada, 2015.

\section{Journal}

Arianta, Ketut, Dewa Gede Sudika Mangku, and Ni Putu Rai Yuliartini. "Perlindungan Hukum Bagi Kaum Etnis Rohingya Dalam Perspektif Hak Asasi Manusia Internasional.” Jurnal Komunitas Yustisia 3, no. 2 (2020): 93-111. https://ejournal.undiksha. ac.id/index.php/jatayu/article/view/28849

Itasari, Endah Rantau. "Implementasi Pemenuhan Hak Pendidikan Warga Negara Indonesia Di Perbatasan Darat Antara Indonesia Dan Malaysia." Jurnal Ilmiah Ilmu Sosial 4 no. 2 (2018): 181-186. https://ejournal.undiksha.ac.id/index.php/ JIIS/article/view/16534

Itasari, Endah Rantau. "Fulfillment Of Education Rights In The Border Areas Of Indonesia And Malaysia." Ganesha Law Review 1, no. 1 (2019):1-13. https://ejournal2.undiksha.ac.id/index.php/GLR/article/view/14/

Itasari, Endah Rantau. "Hak Untuk Pendidikan yang Diterima oleh Masyarakat Indonesia di Perbatasan Darat dalam Persepktif Hak Asasi Manusia." Majalah Ilmiah Cakrawala Hukum 21, no. 1 (2019): 3140. http://e-journal.unwiku.ac.id/hukum/ index.php/CH/article/view/50

Mahardini, I Dewa Ayu Nyoman Alit, Dewa Gede Sudika Mangku, and I. Wayan Lasmawan. "Perlindungan Hukum Terhadap Petugas Medis Dalam Konflik Bersenjata Dalam Perspektif Hukum Humaniter Internasional (Studi Kasus: Penembakan Petugas Medis Razan Al Najjar Di Jalur Gaza)." Jurnal Komunitas Yustisia, 3 no. 1 (2020): 221-230.

Mangku, Dewa Gede Sudika. "Kasus Pelanggaran Ham Etnis Rohingya: Dalam Perspektif ASEAN." Media Komunikasi FPIPS 
12, no.2 (2013): 60-69. https://ejournal. undiksha.ac.id/index.php/MKFIS/article/ view/1708

Mangku, Dewa Gede Sudika and I. Wayan Lasmawan. "Perlindungan Hukum Terhadap Kaum Etnis Uighur Dalam Perspektif Hak Asasi Manusia Internasional." Jurnal Komunitas Yustisia 3, no. 1 (2020): 231240.

Reza, Bhatara Ibnu. "Menguak Penghilangan Paksa: Suatu Tinjauan Dari Segi Politik Dan Hukum Internasional." Indonesian Journal of International Law 1, no. 4 (2004): 769. ijil.ui.ac.id/index.php/home/ article/view/567.

Saragih, Muhammad Fajrin, Sulaiman Hamid, and Makdin Munthe. "Tinjauan Yuridis Pelanggaran Ham Terhadap Muslim Uighur Di China Ditinjau Dari Hukum Humaniter." Journal of USU International Law 4, no.2 (2016): 164. https://jurnal.usu. ac.id/index.php/jil/article/view/13344

Taqy, Raihan, Joko Setiyono, and Soekotjo Hardiwinoto. "Tanggung Jawab Negara Suriah Terhadap Konflik Antara Pemerintahan Bashar Al-Assad Dengan Pemberontak Di Suriah Dari Perspektif Hukum Humaniter Internasional." Diponegoro Law Journal 5, no. 2 (2016): 1-13. https:// ejournal3.undip.ac.id/index.php/dlr/article/view/11146.

Yuliartini, Ni Putu Rai and Dewa Gede Sudika Mangku. "Tindakan Genosida terhadap Etnis Rohingya dalam Perspektif Hukum Pidana Internasional." Majalah Ilmiah Cakrawala Hukum 21, no. 1 (2019): 4149. http://e-journal.unwiku.ac.id/hukum/ index.php/CH/article/view/51

\section{Internet}

Dikarma, Kamran. "Dokumen Tunjukkan Tindakan Keras China Ke Muslim Ui- ghur." REPUBLICA.CO.ID. last modified 2019. https://republika.co.id/berita/ q13ymw328/dokumen-tunjukkan-tindakan-keras-china-ke-muslim-uighur .

"Chinese Torture in East Turkestan." $\mathrm{Ha}$ run Yahya. Accessed January 1, 2021. https://m.harunyahya.com/tr/books/582/ Communist-China's-Policy-of-Oppression-in-East-Turkestan/chapter/66/Chinese-Torture-in-East-Turkestan.

"Human Rights Watch Background Briefings -> Asia -> China." Human Rights Watch. last modified 1999. accessed January 1, 2021. https://www.hrw.org/legacy/backgrounder/asia/china/.

Nursalikah, Ani. "Cina Tindak Keras Muslim yang Berpuasa Ramadhan." REPUBLICA. CO.ID. last modified 2019. https://republika.co.id/berita/pr671p366/cina-tindakkeras-muslim-yang-berpuasa-ramadhan.

(UNICEF), UN Children's Fund. “A Human Rights Approach to UNICEF Programming for Children and Women: What It Is and Some Changes It Will Bring." Refworld. Last modified 1998. https://www. refworld.org/docid/3f82adbb1.html.

\section{Thesis}

Taihitu, bonanza perwira. "Penaatan Indonesia Pada Standar-Standar HAM Internasional Dalam Kurun Waktu 1991-2002." Fakultas Ilmu Sosial dan Politik Departemen Ilmu Hubungan Internasional, Pascasarjana Universitas Indonesia, 2003.

\section{Law and Regulation}

Undang-undang Republik Indonesia Nomor 39 Tahun 1999 tentang Hak Asasi Manusia, Indonesia Legal Center Publishing, Jakarta, Mei 2010.

United Nations, Human Rights, Questions and Answers. New York: United Nations Department of Public Information, 1998. 